\title{
Compound Elevated Skull Fracture: A Clinical Series of Three Patients with a Review of the Literature
}

\author{
Karmaşık Kalkmış Kafatası Kırı̆̆ı: Literatür Derlemesiyle Ü̧̧ Hastalık \\ Bir Klinik Seri
}

Sachin Anil BORKAR, G L PRASAD, D K GUPTA, Sumit SINHA, A K MAHAPATRA

All India Institute of Medical Sciences, Department of Neurosurgery, New Delhi, India

Corresponding Author: Sachin Anil BORKAR / E-mail: sachin.aiims@gmail.com

\begin{abstract}
AIM: Compound elevated fracture of the skull is an unusual variety of fracture of the cranial vault that has been rarely described in the currently available literature. The authors describe three such patients with post-traumatic compound elevated skull fracture. The pertinent literature is reviewed, the injury mechanism is highlighted and the management issues are discussed in detail.

CASE DESCRIPTION: All three patients in this series presented with elevation of free skull fracture fragments above the surface. The mode of injury was rail accident in two patients and injury by a rapidly moving crane in one patient. Two patients had dural laceration with extrusion of brain matter through the dural defect. The remaining patient had an elevated fracture fragment simulating a formal craniotomy with an intact dura. The patient who suffered crane injury was brought dead. Surgery was performed in remaining two patients. Wound debridement and duraplasty was performed. Both patients received broad-spectrum antibiotics in anti-meningitic doses. Both of these patients did well after surgery.

CONCLUSION: Elevated skull fractures are usually compound injuries. High velocity tangential impact to the skull vault is the most likely causative mechanism in such type of injury. Delay in surgery could lead to intracranial sepsis including meningitis and brain abscess. Thus, these fractures should be aggressively treated.
\end{abstract}

KEYWORDS: Skull fracture, Compound, Elevated

öz

AMAÇ: Karmaşık kalkmış kafatası kırığı olağandışı bir kubbe kırığıdır ve literatürde nadiren tanımlanmıştır. Yazarlar post-travmatik karmaşık kalkmış kafatası kıı̆ı̆ı olan üç hasta tanımlamaktadır. İlgili literatür gözden geçirilmiş ve bu yaralanmanın oluşma mekanizması ve ayrıca takibi anlatılmıştır.

YÖNTEM ve GEREÇLER: Tüm hastalar serbest kafatası kırığı parçalarının yüzey seviyesi üzerine yükselmesiyle geldi. Yaralanma modu iki hastada tren kazası ve bir hastada hızla hareket eden bir vinçle yaralanmaydı. İki hastada dural defekt içinden beyin dokusu ekstrüzyonuyla dural laserasyon mevcuttu. Diğer hastada sağlam bir dura ile normal kraniyotomiye benzeyen bir kalkmış kafatası parçası vardı. Vinçle yaralanan hasta ölü getirildi. Diğer iki hastada cerrahi yapıldı. Yara debridmanı ve duraplasti işlemleri gerçekleştirildi. İki hastanın da ameliyattan sonra durumu iyiydi.

SONUÇ: Kalkmış kafatası kırıkları genelde karmaşık yaralanmalardır. Bu tür yaralanmanın en olası nedeni kafatası kubbe kısmına yüksek hızda teğetsel darbedir. Cerrahinin gecikmesi menenjit ve beyin apsesi dahil intrakraniyal sepsise yol açabilir. Bu nedenle, bu kırıkların agresif şekilde tedavisi gerekir.

ANAHTAR SÖZCÜKLER: Kafatası kırığı, Karmaşık, Kalkmış

\section{INTRODUCTION}

Post-traumatic skull fractures are of common occurrence. Skull fractures can be classified as vault fractures or basal skull fractures. Skull vault fractures are conventionally classified into linear, comminuted, or depressed (4). There is another variety of skull fracture in which the fractured fragment is elevated above the level of the intact skull bone. Such fractures, known as "Elevated skull fractures" have been rarely described in the currently available literature regarding this topic $(1,2,3,5,6)$. The authors report a clinical series of three patients with compound elevated fracture and review the literature regarding the same.

\section{CASE DESCRIPTION}

\section{Case I:}

A-twelve-year-old boy presented to our emergency service after sustaining head injury by a rapidly moving train. He was injured near the railway track when a fast moving train hit him on the right temporo-parietal area. He was thrown away by about 10 metres. On presentation to the emergency department four hours after injury, his vital parameters were stable. The Glasgow Coma Scale (GCS) score was E4V4M6. $\mathrm{He}$ had right-sided hemiparesis - power $3 / 5$. There were no associated systemic injuries. He had a wound in right parietal 
region where there was no bone and the contused brain was herniating out through the scalp and dural defect (Figure 1A). Urgent non-contrast computerized tomography (NCCT) head revealed an elevated skull fracture of right parietal bone with underlying brain laceration with herniation of brain tissue to the exterior via the dural defect (Figure 1B). He was immediately taken to operating room where thorough wound debridement and contusectomy was done. Dural repair was performed using a pericranial graft (Figure 1C). The scalp defect was closed by local advancement technique. The patient was prescribed intravenous broad-spectrum antibiotics along with cerebral decongestants and anti-seizure medications. He was discharged on seventh post-operative day in $\mathrm{E} 4 \mathrm{~V} 5 \mathrm{M} 6$ status with residual right hemiparesis. On last follow-up visit, he was doing well.

\section{Case II:}

A 20-year-old man was brought to our emergency unit with alleged history of railway accident four hours prior. He was unconscious. Eyewitnesses revealed that he was travelling in an overcrowded suburban local train and part of his body was outside the moving train. He sustained injury when his head struck against the electric pole installed by the side of railway track.

At presentation, he was hemodynamically stable with normal pulse and BP. There were no associated injuries. His postresuscitation Glasgow Coma Scale (GCS) score was E1VetM2. Pupils were bilateral normal size sluggishly reacting to light.

Local examination revealed that there was traumatic avulsion of calvarium along with the scalp flap in the left frontoparietal region. The underlying dura was intact and the bone flap was so avulsed that it was simulating a formal frontoparietal craniotomy (Figure 2A). Non-contrast computerized tomography (NCCT) of the head with a bone window confirmed these findings. In addition, there was underlying left frontal contusion and traumatic subarachnoid haemorrhage (SAH ) (Figure 2B, C). Debridement of the wound was done in emergency. The bone flap, in view of gross contamination, was removed and stored in bone bank. Dura was found to be intact and hence not opened.

The patient was prescibed antibiotics per departmental antimeningitic protocol, along with mannitol and phenytoin. The patient was tracheostomized and was gradually weaned off from the ventilator and decannulated. He improved to E2V1M5 status, was discharged and is now on regular followup.

\section{Case III:}

A 35-year-old-male patient was brought by police to emergency department with history of having sustained trauma by a crane. The eyewitness to the accident recalled that the victim was driving a motorcycle when a crane involved in a bridge work suddenly came down over his head hitting his skull from superolateral direction. On examination, patient was E1V1M1 with absent brainstem reflexes and no cardiac activity. He had compound elevated fracture of left frontoparietal region with dural breach exposing the brain to the exterior (Figure 3). As the patient was dead, CT head was not performed and the relatives were informed.

\section{DISCUSSION}

Post-traumatic skull fractures are usually depressed fractures. This is because the mechanical force in calvarial fracture is mostly directed inwards, which drives the fragment intracranially, resulting in a depressed fracture. However, in some cases, a tangential force applied to the calvarium elevates the fracture fragment by a lateral pull of the object or rotation of the head resulting in elevated skull fracture (2). This may be the most likely injury mechanism in our cases. Sometimes, an elevated skull fracture may simulate a formal

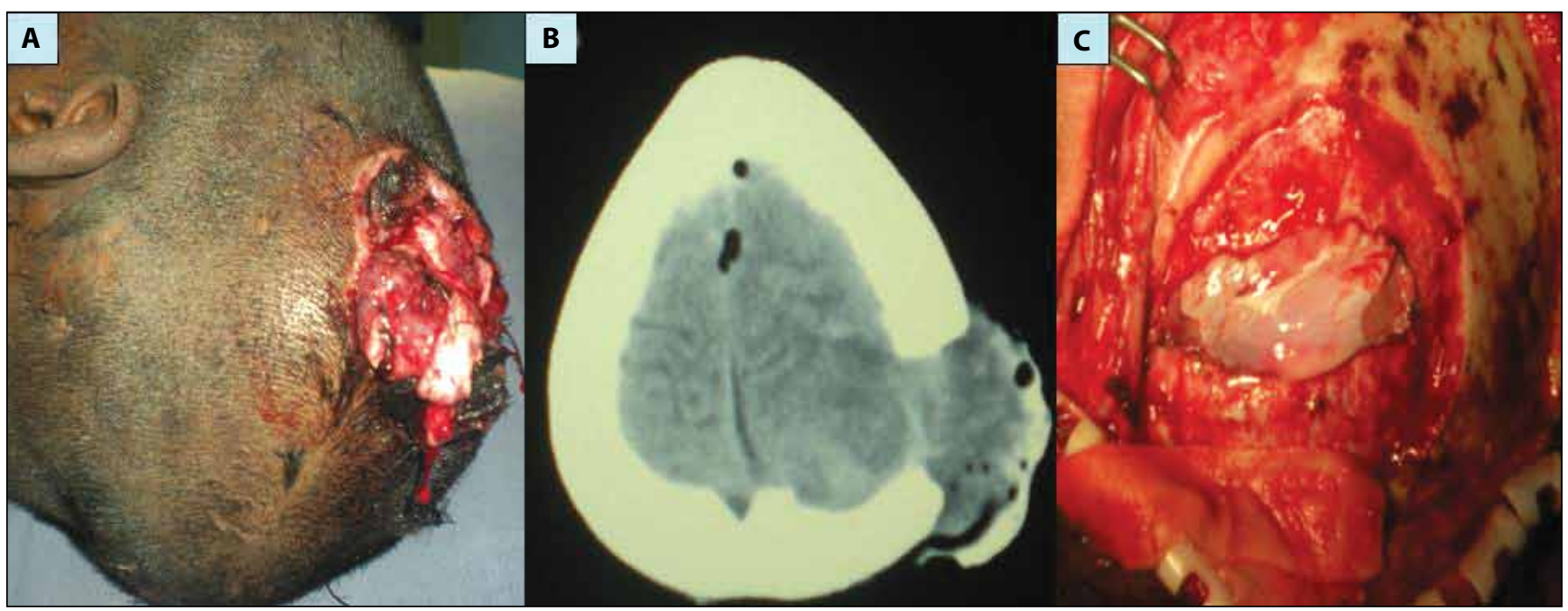

Figure 1: Clinical photograph (A) of the patient showing herniation of contused cerebral tissue through a left parietal compound elevated fracture. NCCT head showing similar findings (B). Intra-operative photograph of the patient (C) showing repair of the dural defect with pericranial graft. 


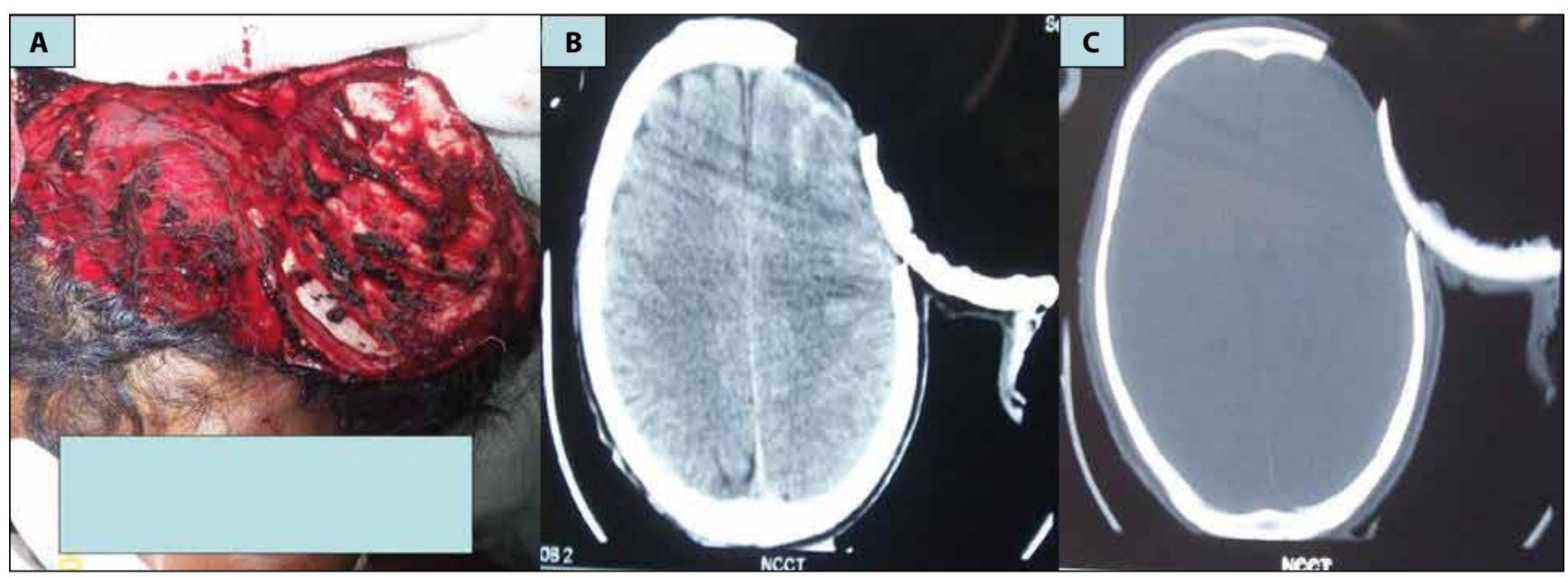

Figure 2: A) Clinical photograph of the patient showing avulsion of calvarial bone flap simulating left frontoparietal craniotomy. Note the dura is intact. Non-contrast Computerized Tomography (NCCT) head (B) and bone window (C) showing elevated fracture left frontoparietal bone with underlying left frontal haemorrhagic contusion and traumatic subarachnoid haemorrhage (SAH).

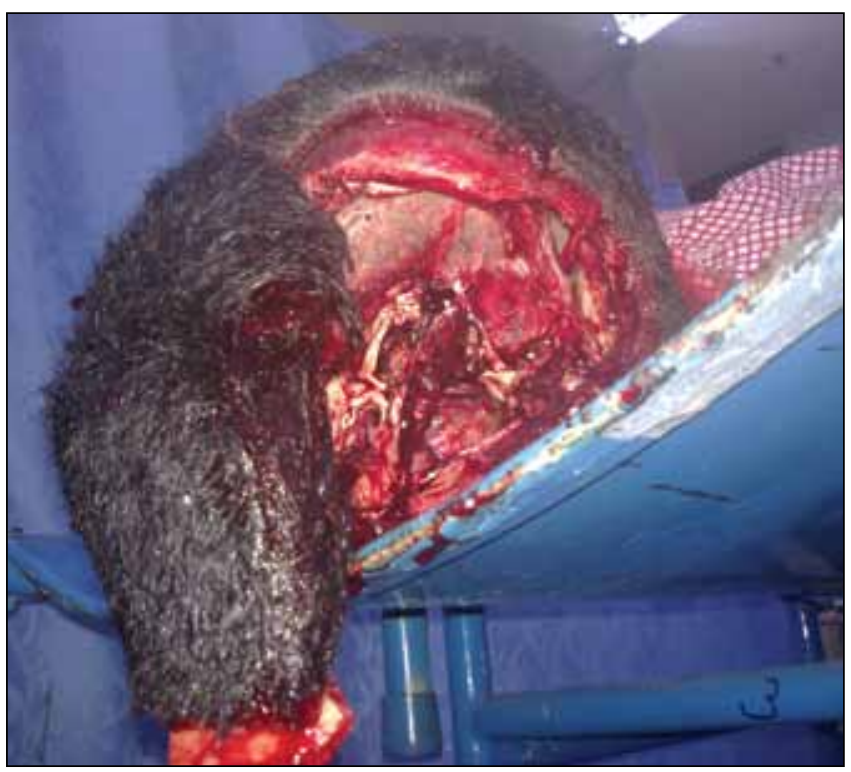

Figure 3: Clinical photograph of the patient showing compound elevated fracture of left frontoparietal region with dural breach exposing the brain to the exterior.

craniotomy as reported in some of the cases $(2,3)$. Elevated fractures are always compound as earlier reported $(3,5,6)$. Dural breach is mostly present. However, in one of our cases (case II), the dura was intact which is quite unusual considering the high velocity of impact. The severity of injury and the resultant neurological manifestations can vary, as exemplified in our cases. One of our patients was neurologically preserved (case I), whereas the other patient probably died on the spot or during transport to the hospital (case III). Non-contrast CT head is the preferred investigation as it clearly shows the bony details. It also detects associated intracranial haematoma, contusions or subarachnoid haemorrhage; all of which are associated with a worse prognosis (3). The ultimate prognosis, however, depends upon underlying brain injury and prompt and aggressive surgery.

An elevated fracture of the skull should be managed on the lines of an open depressed skull fracture on an emergent basis because any delay may be complicated by meningitis and intracranial sepsis. Extensive wound debridement should be carried out with antiseptic solutions (3). Dural breach, if present, should be repaired primarily or by using a pericranial or temporalis fascia graft, as we have done in case I. The patient should be given broad-spectrum antibiotics in antimeningitic doses to prevent meningitis. It is prudent not to replace the bone flap at the time of primary surgery min view of potential contamination. Delayed cranioplasty is ideal once the patient recovers, either with autologous bone graft or synthetic cranioplasty material (3).

\section{CONCLUSION}

An elevated skull fracture is an uncommon injury caused by a high-velocity tangential force applied to the vault of the skull. It is frequently compound and should be managed aggressively as that of an open depressed skull fracture with thorough wound debridement, dural repair with broadspectrum antibiotics. With aggressive treatment, a good result is possible in spite of the nature and extent of injury. 
Table I: Summary of Cases of Compound Elevated Fracture

\begin{tabular}{|c|c|c|c|c|c|c|c|}
\hline $\begin{array}{l}\text { Sr } \\
\text { no. }\end{array}$ & Age/sex & Mode of injury & $\begin{array}{l}\text { GCS at } \\
\text { presentation, } \\
\text { Condition at } \\
\text { presentation }\end{array}$ & CT findings & $\begin{array}{l}\text { Intervention } \\
\text { performed }\end{array}$ & $\begin{array}{l}\text { GCS at } \\
\text { discharge, } \\
\text { Condition at } \\
\text { discharge }\end{array}$ & Follow-up \\
\hline 1 & $\begin{array}{l}12 \\
\text { years/M }\end{array}$ & $\begin{array}{l}\text { Injury by a } \\
\text { rapidly moving } \\
\text { train. }\end{array}$ & $\begin{array}{l}\text { E4V4M6, } \\
\text { Rt hemiparesis } 3 / 5 \text {, } \\
\text { wound in right } \\
\text { parietal region where } \\
\text { there was no bone } \\
\text { with herniation of } \\
\text { contused brain was } \\
\text { through the scalp } \\
\text { and dural defect } \\
\text { (Figure } 1 \mathrm{~A} \text { ) }\end{array}$ & $\begin{array}{l}\text { Elevated skull } \\
\text { fracture of right } \\
\text { parietal bone with } \\
\text { underlying brain } \\
\text { laceration with } \\
\text { herniation of brain } \\
\text { tissue to the exterior } \\
\text { via the dural defect } \\
\text { (Figure 1) }\end{array}$ & $\begin{array}{l}\text { Wound } \\
\text { debridement, } \\
\text { contusectomy } \\
\text { and dural } \\
\text { repair (Figure } \\
\text { 1C) }\end{array}$ & $\begin{array}{l}\text { E4V5M6 } \\
\text { status with } \\
\text { residual right } \\
\text { hemiparesis }\end{array}$ & $12 \mathrm{~m}$ \\
\hline 2 & $20 \mathrm{yrs} / \mathrm{M}$ & $\begin{array}{l}\text { Rail accident, } \\
\text { head struck } \\
\text { against the } \\
\text { electric pole } \\
\text { installed by the } \\
\text { side of railway } \\
\text { track. }\end{array}$ & $\begin{array}{l}\text { E1V1M2, } \\
\text { traumatic avulsion } \\
\text { of calvarium along } \\
\text { with the scalp flap in } \\
\text { the left frontoparietal } \\
\text { region (Figure } 2 \mathrm{~A} \text { ). }\end{array}$ & $\begin{array}{l}\text { left frontoparietal } \\
\text { bone elevated } \\
\text { fracture along with } \\
\text { underlying left } \\
\text { frontal contusion } \\
\text { and traumatic } \\
\text { subarachnoid } \\
\text { haemorrhage } \\
\text { (Figure } 2 \mathrm{~B}, \mathrm{C} \text { ) }\end{array}$ & $\begin{array}{l}\text { Wound } \\
\text { debridement }\end{array}$ & E2V1M5 & $6 \mathrm{~m}$ \\
\hline 3 & $35 / \mathrm{M}$ & $\begin{array}{l}\text { Crane injury, } \\
\text { crane involved } \\
\text { in a bridge } \\
\text { work suddenly } \\
\text { came down } \\
\text { over the head } \\
\text { hitting the } \\
\text { skull from } \\
\text { superolateral } \\
\text { direction. }\end{array}$ & $\begin{array}{l}\text { Brought dead, } \\
\text { compound elevated } \\
\text { fracture of left } \\
\text { frontoparietal region } \\
\text { with dural breach } \\
\text { exposing the brain to } \\
\text { the exterior } \\
\text { (Figure 3) }\end{array}$ & CT not performed & - & - & - \\
\hline
\end{tabular}

\section{REFERENCES}

1. Adeolu AA, Shokumbi MT, Malomo AO, Komolafe EO, Olateju SO, Amusa YB: Compound elevated skull fracture: A forgotten type of skull fracture. Surg Neurol 65:503- 505, 2006

2. Aniruddha TJ, Indira Devi B, Arivazhagan A: Traumatic avulsion of cranial bone flap simulating craniotomy. Indian Journal of Neurotrauma (IJNT) 5:53, 2008

3. Borkar SA, Sinha S, Sharma BS: Post- traumatic compound elevated fracture of skull simulating a formal craniotomy. Turk Neurosurg 19:103-105, 2009
4. Kaye AH: Head injury. In: Kaye AH, Essential Neurosurgery. Singapore: Churchill Livingstone (ed), 1991:59- 80

5. Ralston BL: Compound elevated fractures of the skull. Report of two cases. J Neurosurgery 44:77 - 78,1976

6. Verdura J, White RJ: Compound elevated skull fractures. J Neurosurgery 45:245,1976 